\title{
Murdoch University
}

\author{
Mags Webster
}

Witches' butter, golden spindles, bell-shaped mottlegill'1 ${ }^{1}$ the multiple identities of the prose poem

\begin{abstract}
:
This paper explores the challenge of ineffability, with a focus on prose poetry. It considers the strengths of the prose poem in offering a semantic or communicative means (Spackman 2012) of drawing closer to the unsayable, and situates this exploration in the wider context of apophasis, a centuries-old rhetorical device developed to deal, in language, with what lies beyond language. Investigating the nature and identity of prose poetry, the paper examines a prose poem by Yusef Komunyakaa, discussing its efficacy in relation to an apophatic approach to technique and form. Adopting a creative voice, and weaving prose poetry throughout the discussion, this paper also endeavours to show the overlap of creative process and practice within a research context, executed through the combination of form, idea, reflection and enquiry. In offering an amalgam of prose and poetry, the critical and the creative, this paper is not only reflecting on the situated experience of apophasis with regard to prose poetry, but also actively employing it.
\end{abstract}

\section{Biographical note:}

Mags Webster is a PhD candidate at Murdoch University, Western Australia. She holds an MFA in Creative Writing (poetry) from City University of Hong Kong, a BA with First Class Honours in English and Creative Writing from Murdoch University, and BA (Hons) in English and Drama from the University of Kent. Her poetry, prose and reviews have been published in journals and anthologies in Australia, Asia and the US. Most recent publications include poems in The Fremantle Press Anthology of Western Australian Poetry (2017) John Kinsella \& Tracy Ryan (eds); The Golden Shovel Anthology: New Poems Honouring Gwendolyn Brooks (2017) Fayetteville: University of Arkansas Press; and Afterness: Literature from the New Transnational Asia (2016) Hong Kong: After-Party Press. Mags's book, The Weather of Tongues (Sunline Press), won Australia's 2011 Anne Elder Award for best debut poetry collection.

Keywords:

Prose poem - Apophasis - Ineffability - Creative practice 


\section{Introduction: Taxonomies of forest steak}

Twenty-five years ago Science published a paper called 'Monophyletic origins of the metazoa: an evolutionary link with fungi', in which four researchers reported identifying 'a conjoint evolutionary history for animals and fungi' (Wainwright et al 1993) through the analysis of amino acid sequences. The conclusion? Despite fungi's appearance and habitat, closely allied to plant ecology, these scientists offered proof that these organisms are biologically and evolutionarily closer to animals than plants.

If prose poetry could be opened up to such forensic analysis, could the questions of taxonomy that have been raised in relation to it be settled, once and for all?

Destroying angel. Dryad's saddle, poem, amethyst deceiver, crimson wax cap, prose. Bereft of words to word you, instead I copy lists, taxonomies of forest steak. I read unseeing pages in my hand, ad lib of lines, the blue-green clitocybe, clustered toughshank, cramp ball, hairy stereum.

Prose or poetry? A conflation of the two? Should prose poetry be regarded as genre or as form (terms which are themselves often conflated)? If genre, to which one does it belong? If form were judged by a sliding scale, would the prose poem veer closer to free verse or to flash fiction? Yet, is this apparent slipperiness not entirely the point if, as suggested by Marjorie Perloff in 'The Linear Fallacy', the prose poem is one of the 'alternate modes of writing poetry ... created by artists who felt that traditional accentual-syllabic meters were alien to their experience, that experience was itself fluid, shifting, nondefinable' (Perloff 1981: 868)?

No wonder scholar and poet Kevin Brophy observes that this 'species' (my term) of writing 'constantly problematises its nature, threatening to be one thing and refusing to be another' (Brophy 2003: 179). Sometimes when approaching texts, we fall into tramlines of habit and expectation, the appearance of lines or sentences becoming, as Perloff suggests, 'no more than a surface device meant to arrest our attention' (Perloff 1981: 864), and steer our response accordingly. But (and with the prose poem especially) we do this at our peril. Prose poetry can pose fundamental questions of poetics, as Brophy suggests:

What the prose poem does is ask, over and over, what are the rules of the verbal game we call poetry ... Whose rules are they? Whose rules were they? Where are the rules? What rules can apply when the ineffable is the aim? (2003: 178)

What rules indeed? Did not Stéphane Mallarmé, a leading proponent of the prose poem, write 'the intellectual armature of the poem is to be concealed ... in the space which isolates the strophes amid the white of the paper; significant silence which is not less beautiful to compose than the verse' (Mallarmé in Bruns 2001: 114)?

In this paper I explore the prose poem from the perspective of language, meaning and ineffability, and in particular with the effect of ineffability on modes of writing (poetry specifically) that attempt to engage in words, with what lies beyond words. My essay 'essay' in the original sense of the word, from the Old French essai as in 'to try out' 
reflects on the nature and identity of prose poetry, and weaves in attempts at prose poems themselves. Discoveries unfold on the field of the page; they are incidental upon each new combination of words or rearrangement of sentences. Sometimes I stumble on unforeseen revelations or impasses, which make me alter course. In an exploration such as this, one observation, however tangential or seemingly insignificant, is consequent upon another, and integral to the whole. Thus both discourse and prose poem passages (which sometimes merge) seek to trace a progression: a creative and theoretical examination of prose poetry.

This combining of form, idea, reflection and enquiry also endeavours to show a record of how my creative process and practice both overlap with and are the research underpinning this discussion. It is my experience that all these elements are all so closely interwoven they cannot be separated: so this paper demonstrates a sampling of patterns of language, argument and thoughts that typically accrete as I ponder the conundrum of how to address the ineffable in my writing, and attempt to "solve" it through different, and sometimes (to me) less familiar structures, such as the prose poem.

Who are you? Making me stumble on this field of silence. Wood woolly-foot. Letting me woo you in my softest shoes, hoping to coat you in a skin of cashmere. I want to loosen you, to play you, eat you after dark.

\section{Not a painter}

Ineffability, from the Latin ineffabilis (unutterable), is defined as 'that [which] cannot be expressed or described in language; too great for words; transcending expression; unspeakable, unutterable, inexpressible' (OED 2017).

Ever since humankind began, as scholar William Franke puts it, 'butting up against the limits of language' (2014: 23) in an attempt to articulate the unknown and unknowable, the question of ineffability has threaded philosophical, poetic, and theological discourse. Even before Plato, writers and thinkers in both Eastern and Western traditions have grappled with it, in an attempt to engage spiritually, creatively or theoretically with inexpressible concepts, such as the nature of God. To do this, they used apophasis ${ }^{3}$, the rhetoric of negation, or the practice (as in the case of Christianity from the fifth century CE onwards) of speaking about God in terms of what God is not, rather than what God is. ${ }^{4}$

An investigation into apophasis and its relationship to ineffability is to be found in the texts of the early Christian mystics such as Dionysius the Areopagite (1978) and Marguerite Porete (2007); of Sufi poets such as Rumi (1898, 1994); and authors including Emily Dickinson (1959, 1971, 1975), TS Eliot (1974), Don Paterson (1999), Charles Wright (2000, 2002, 2003), and Samuel Beckett (1959). More recent discourse has tended to use apophasis to examine questions of an epistemological and semiotic nature. This discourse - sometimes called negativity or negation, sometimes 'the unsayable' - has variously been taken up by Ludwig Wittgenstein (1961), Martin Heidegger (1971); Heidegger (2000) with reference to the work of Hölderlin, Jacques 
Derrida (1982, 1995, 1996), and Giorgio Agamben (1991); and usefully expanded by scholars such as Franke (2007, 2014), Michael A Sells (1994), and John D Caputo (1997).

In the last sixty years, reflection on the nature of ineffability has expanded to encompass the expressive qualities of the arts, especially music and visual arts, via the development of analytic aesthetics within philosophy. ${ }^{5}$ Scholar John Spackman divides ineffability into two streams: semantic and communicative, explaining,

To say that an experience or an item of knowledge is semantically ineffable is to say that it is not captured by the meaning of any words. To say that an experience or some knowledge is communicatively ineffable is to say that it cannot be conveyed to others by the means of words. (Spackman 2012: 304; emphasis in original)

The thesis with regard to the arts, as Salvador Rubio Marco explains following Spackman (2012), rests on the argument 'that works of art possess expressive qualities that cannot be captured by literal language, or cannot be captured by any type of language at all, whether it be literal or non-literal' (Marco 2016: 393).

Prose poet Russell Edson observes that 'the poet has to create into language something that has no language' (Edson 1999). Why not paint instead, one might ask? But even if this were a preferable option, to echo Frank O'Hara, I 'am not a painter, I am a poet' (O'Hara n.d.). Nevertheless, as a poet, I am 'condemned to words' (Alazraki 1976: 41). ${ }^{6}$ However, could I tilt with how I arrange words and spaces, and enact what Edson proposes: 'to create into language something that has no language' (Edson 1999)? Accordingly, and drawing on the lyric tradition as practised by Dickinson, Eliot and Wright, I have been exploring ways of composing 'significant silence' (Mallarmé in Bruns 2001: 114) poetically, considering space, absence, stasis and silence as proxies for the ineffable, and experimenting with how poetry might frame them.

Brophy's questions relating to the 'verbal games' (Brophy 2003: 178) of the prose poem's quest for ineffability may be rhetorical, yet they prompt a practical and theoretical enquiry into the value of prose poetry in addressing the challenge of ineffability. What qualities, what differences, what advantages might prose poetry have that could prove productive, in terms of creative process as well as poetic effect? Could the prose poem be a way to follow Edson's lead? A better acquaintance with the prose poem's provenance and its relevance to apophasis is required in order to address those questions.

I know your other self - unbuttoned, fey, unproseable - a drift of silk, ragroll of frost on glass. Clasped by rooms of ice, you wear your architecture lightly, can be perpetual melt; you are mutability. But when suited, straight-seamed, you become inscrutable. Is it your label, how you look, or more? Are you hiding yet another self from me? Are you prose that wants to be a poem? Poetic prose? Prosaic poetry? Who are you? 


\section{Mixed form, mixed messages}

According to a widely-held view, ${ }^{7}$ prose poetry emerged as an acknowledged form in nineteenth-century France, chiefly through Arthur Rimbaud and Charles Baudelaire. However, there are some who hold a different view. Poet Morton Marcus argues that prose poetry began two millennia before in China, 'during the Han Dynasty (206 BC220 AD), where it was known as fu, or rhymed prose' (Marcus 1999). Poet and critic Andrew Zawacki refers to the research of medievalist Peter Dronke, who suggests that evidence of hybrid prose/poem texts survives from before the birth of Christ, and 'came to be known as prosimetrum' (1994: 2) (emphasis in original), a Latin word suggestive of metred prose. ${ }^{8}$ Dronke contends that these 'unusual uses of the mixed form' (1994: 4) reached their apogee in vernacular texts of the thirteenth century, with the work of medieval mystics such as the French beguine Marguerite Porete, and Mechthild of Magdeburg in Germany (1994). Citing Porete, whose most noted work is Mirouer des simples ames (The Mirror of Simple Souls ca.1285-95, ${ }^{9}$ Dronke explains:

The poetry grows out of the prose and grows back into it. Prose sentences spill over into lyrical passages ... often, too, if the prose itself is charged with lyricism, it changes gradually ... into a more regular pattern. (1994: 96)

According to Franke, Porete's text, which was translated from Old French into several languages is 'a model of ascetic spirituality and apophatic theology' (Franke 2007: 277), and 'Marguerite acknowledges that, by attempting to write, she "undertook a thing which one cannot say"' (Franke 2007: 278).

Dronke's analysis of Porete's work helps to situate apophatic writing within a discussion about the prose poem. Though I have not yet come across any prose poems specifically employing apophatic language during my research, it seems to me that much contemporary prose poetry, though secular in impulse, resonates with a tempo, diction and lyrical mystery similar to early Christian apophatic texts, and also to the psalms.

The (often anonymous) monks, anchoresses, clerics and laity of early Christianity were writing prayers and contemplative texts in the form of prayer, instruction and apostrophe (an address to someone who is not present). ${ }^{10}$ The apophatic style in which they were writing helped them, if not to overcome the problem of referring to the unknown and the transcendent (i.e. God), then at least to codify it in a way that would be understood by contemporary worshippers. The following (anonymous) fourteenthcentury translation of an extract from the sixth-century text The Mystical Theology attributed to Dionysius ${ }^{11}$ is typical of the diction employed by ecclesiastical scribes:

$\mathrm{He}$ is none of the things that have no being, none of the things that have being. None of the things that are known know him for what he is ... he has no name; we cannot know him; he is neither darkness nor light, error nor truth. (Dionysius in Wolters 1978:

In this passage, the denial in both what is said and the way it is said is totally apophatic, yet the effect is the opposite of delimitation. God cannot be defined; thus God is of and in and beyond everything and nothing. In effect, what can be said releases what cannot. And in another twist, what can be said is only achieved through elimination and denial. 
So how are texts like these, originally in Latin or Greek, translated centuries later into vernacular English, linked to my interest in contemporary prose poetry and its possible relationship to ineffability? What, in any case, is prose poetry?

As the Princeton Encyclopedia of Poetry and Poetics notes, genre is 'contingent, historical', its 'identifying features' dependent on 'writers' tendencies and readers' expectations' (Cavitch in Cushman et al 2012: 1055). This contingency has been reflected in various commentaries on the prose poem. For example, in an introduction to an issue of The Mississippi Review devoted to the prose poem, Julia Johnson writes 'the prose poem as a form has almost reinvented itself. It no longer seems like a separate genre, though of course I know many would disagree' (Johnson 2006: 8-9). Juan Manuel Sànchez dubs it 'eccentric' and 'enigmatic', adding that this stems from 'the question of the prose poem as hybrid form or genre (never mind the term itself) with downright divergent approaches and results' (Sànchez 2009: 175). Poets and scholars Paul Hetherington and Cassandra Atherton identify the classification of the prose poem as a site of conjecture, remarking that:

If the broad classifications we apparently summon up by the terms 'poetry' and 'prose' may not denote clearly definable literary forms - although various forms, such as narrative poetry or the novel, are usually assumed to be a category of either poetry or prose, but not both - and if the broad classifications we call 'poetry' and 'prose' are more elusive than we would often assume, then the prose poem may be a demonstration of how certain kinds of literary works are unclassifiable, or perhaps even extra-generic - in this case, both poetic and prosaic at once. (2015: 268)

A cup of blossoming tea. Osmanthus, pregnant stillness first, leaf-shy - what is this then a tentative expansion. Panicles detaching one by one, floating on a ballast of aroma, kissing surface steam before a fall, fattening with flavour. Pollen, spreading oily iridescence. Life in life-lapse, slow to quicken, fraying into stasis. Molecule by molecule, awakening of attar. Stillness, flare of petal, then repose. Time blooming. Time astringent. Tension unconditional.

\section{I love a poem in uniform}

One of the most beautiful - and musical - prose poems I have ever experienced is 'A Reed Boat' by American poet and Vietnam veteran Yusef Komunyakaa (in Kuusisto 1995: 143). I find 'A Reed Boat' all the more seductive because it is a prose poem: somehow it should not be able to offer something as achingly beautiful within such a plain format. On the page, there is no light tethering of lines and breaks, but content boxed within paragraphs, like a news report or a letter. Yet if anything, the poem's prosaic 'uniform' heightens its musical and poetic impact.

Split into four roughly equal paragraphs, 'A Reed Boat' traces not only a narrative, but also the slow development of the speaker's reaction to the Hanoi lakeside scene he is surveying, giving the reader access to the projector of his mind. The subject matter straddles material and mythical worlds: a boat initially 'tarred and shellacked to a waterrepellent finish' has turned, by the last paragraph, into the 'boat of Ra.' There is the hint of a love story being recalled against the background of a long-past war, in the way that 
the boat is 'light as a woman in love', being handled in a languorous fashion because 'there isn't the shadow of a bomber on the water anymore'. The poem is highly schematic, Komunyakaa playing with the idea of twos, oppositions and halves: the 'real' and the imaginary, day and night, the surveyor and the surveyed, the boatman's movements 'left and right, reaching through and beyond', the speaker feeling that he and the boatman are 'the only two left in the world', blossoms 'snapping themselves in half' in a lagoon where 'anything with half a root or a heart could grow'. Continuing this dyadic theme, there is interplay between past and present, memory and the present. Komunyakaa harnesses prose poetry's supreme ability to alternate between 'pause' and 'play':

There's a pull against what's hidden from day, all that hurts. At dawn, the gatherer's shadow backstrokes across water, choreographed for an instrument played for gods and monsters in the murky kingdom below. Blossoms lean into his fast hands, as if snapping themselves in half, giving into some law. (Komunyakaa in Kuusisto 1995: 143)

To elaborate, this second paragraph of 'A Reed Boat' has a cinematic quality in the way the speaker's vision pans across the wider vista (dawn light, the shadows across the water) and zooms into detail (blossoms, hands). At the same time, a mythical scenario is playing out (what's hidden, gods and monsters, the murky kingdom), paralleled by the hint of some personal back-story (a woman in love, all that hurts, giving into some law). All these elements knit seamlessly in language that suggests how they should ('choreographed', 'pull against', 'lean into', 'giving into'), and yet there are moments when this fluidity is interrupted ('all that hurts', 'backstrokes', 'snapping themselves in half'). In subject matter as in syntax and diction, the dynamic of the poem's ebb and flow is effortlessly deployed.

The poem's style and form also embody an incremental patterning in the partnership between prose and poetry: formality softening to fluidity, chance starching to convention, and precision of detail recounted with a conversational ease. As Brophy, drawing on Canadian writer and poet Robert Allen suggests, in prose poetry 'there is no separation of genres, only writing through a continuum of merging forms' (Brophy 2003: 176).

If Komunyakaa had chosen to arrange 'A Reed Boat' into line breaks and stanzas, this would still be a compelling piece. But for me, its modest, prose-coated, 'not-poem' presence on the page exalts it into something numinous; or as Spackman might say, 'semantically' ineffable (Spackman 2012: 304). Despite this, I will attempt to explain how the poem does so.

Discussing prose poetry, poet James Longenbach notes 'the absence of the line would not be interesting if we did not feel the possibility of its presence' (Longenbach 2008: 88). I wonder if part of 'A Reed Boat's' seductiveness lies in this tension between absence and presence, this unspoken yet almost erotic charge caused by the disjunction between my assumption that prose usually offers something expressively less than poetry - thus fulfilling Perloff's comments about 'surface device' - and what 'A Reed Boat' is actually offering me: an experience that confounds all these expectations, and trumps my ability to explain them. 
As I read, I am conscious of a gravitational pull into the poem's world, and the lap of its language, which demands closer attentiveness lest I miss a detail. Once I am inside 'A Reed Boat', I am not sure whether I stand next to the voice 'on the steps of Hanoi's West Lake Guest House', or whether I am inside the voice; at times, I feel almost like I am the reed boat itself, 'just sway-dancing with the current's ebb'. But then perhaps that is the point, in this poem that is like a dream: the reader identifying with the speaker who is identifying with the boat, and the rower; perhaps we are all the boat, we are the speaker, we are the inhabitants of the murky kingdom below, the rower, the woman in love, the lotus blossoms, the lagoon. Yet when the speaker - probably (but not definitely) addressing the boatman - says in the penultimate sentence of the poem, 'it's hard to act like we're the only two left in the world', I feel just the opposite, which is perhaps also the point. I feel that the speaker and I, the poem and reader, are the only two left in the world, this world that the poem has created. The ending of the poem, 'He balances on his boat of Ra, turning left and right, reaching through and beyond, as if the day is a woman he could pull into his arms', reprises the hint of something precious lost. And all of a sudden, I am back on the outside of the poem, in that perspective created by distance, yet vibrating with everything the poem has evoked but has not said. Nor, given the instinctiveness and intensity of my reaction, has needed to say.

Poet John Drury suggests that prose poems 'may seem like stories, or essays, or descriptions, but some quality of radiance or charged language qualifies them as poems' (Drury 1991: 71-2). The writings of the mystics and Komunyakaa are separated by hundreds of years, widely differing social and cultural contexts and rhetorical styles. Yet the dignified, prosimetric approach of mystics such as Dionysius and Porete evoke, for me, a similar measure and meditative 'quality of radiance' (Drury 1991: 72) to Komunyakaa's poem. They are examples of text where, although the subject matter may deal with something semantically ineffable, i.e. that cannot be captured by any language, the writing is not however communicatively ineffable: it succeeds in conveying 'an experience or knowledge ... by the means of words' (Spackman 2012: 304).

Ultimately, I am more drawn to 'A Reed Boat', but then I am a twenty-first century agnostic rather than a devout fourteenth-century penitent; that I would gravitate towards poetry rather than prayer is hardly surprising. Yet if there is such a thing as secular prayer, then surely prose poetry is a likely candidate? Having looked at another poet's work, I must now move towards grappling with my own.

\section{The monster child}

It has been called a 'defiant formlessness' (Brophy 2003: 176); 'an appeal to illogic' (Shapcott 2002); 'the monster child' (Simic in Zawacki 2000: 300); a 'mysterious man with an accent' (Novey 2013), 'a naked way to write' (Edson 1999). "'Strangely like" both poetry and prose without clearly being one or the other' (Hetherington and Atherton 2015: 265), it is a free spirit, genre-neutral, genre-fluid: not quite poetry, not quite prose, and not quite neither. Yet although some label it as 'poem written in prose rather than verse' (Lehman 2003: 45), any attempt to lock prose poetry down in binary terms 'ignores its true complexity' (Caplan in Zawacki 2000: 293). While not lyric 
poetry as it is conventionally understood, the prose poem is innately lyrical, musical. Philosopher George Steiner suggests that:

By a gradual loosening, or transcendence of its own forms, the poem strives to escape from the linear, denotative, logically determined bonds of linguistic syntax into what the poet takes to be the simultaneities, immediacies, and free play of musical form. (1967: 62)

Steiner may have been writing about lineated poetry, but to me, his observation identifies how the material of a prose poem (as with any poem, successfully rendered) is able to transcend its verbal structure, and hover as an acoustic of the inexpressible.

Paradox is integral to the prose poem, which contains both volatility and stasis. Prose sentences, which could ordinarily be considered less demanding than poetic lines to read and understand, are - in the context of prose poetry - challenging and unsettling.

It seems that heightened or 'poetic' language, presented as or in prose - tidily justified and appearing as an apparently static, modest-looking block of text - can invoke a reading experience in which the reader feels they are being first drawn inward then pushed outward. Perhaps because prose poetry eschews line breaks, the considered scoring on the page that verse poetry uses to indicate pace and pause, the shape a prose poem makes on the page is a solid presence, an enigmatic, black-hole density, which seems to suck the reader inward. Then, while the reader is absorbing the effect of this force-field, and working through the subtleties of the prose poem's internal structure, something detonates within the writing - something that is beyond words and form and the poem begins slowly to expand outwards. This motion expels the reader, yet creates a distance and a perspective that enables comprehension. As Hetherington and Atherton have noted, 'prose poems frequently open up, TARDIS-like, to reveal much more than their actual size on the page would appear to allow' (Hetherington and Atherton 2015: 272). Crucially, there will be a hinge moment between centripetal and centrifugal motion when time seems to stop, and the poem 'turns on an anxiety of space' (Hetherington and Atherton 2015: 275) before resuming its movement.

Why 'an anxiety'? What sort of 'space'? Are the prose poem's limits hermetic and compressed, or endlessly permeable and elastic? Is a prose poem a worded silence that slowly gestates into sound? Or is it already a saturation, a fullness that ultimately recedes into emptiness? A verbal, temporal, and spatial shape-shifter, the prose poem both inspires and defies description; and, as I discover, it inspires and defies composition.

Are you a unit of stillness? (Unit: ugly word, prosaic. Must do better.) Simply, are you stillness? I think you are ... but then you seem to move. Perhaps it's how you sit, a wedge of words on page ... no slant rhyme, waltz of dactyl, apse of lines. Tonight you dress as concentrate, spondee; a glut, a cluttering of dots and markings. You're autumn, fallen onto snow. Yellow stainer, poison pie, dung roundhead, wrinkled club. 
A prose poem looks as though it might be straightforward to write (just a few sentences, no fretting about line breaks), but it is not. It appears a little conservative - boring even - on the page (a solid plod of text from left to right), but appearances are deceptive. It looks as if it may be easy to read - this is prose, after all, no scary handbrake turns of text, no 'I am a sonnet, am I Petrarchan or Shakespearean?' self-referential malarkey but to read a prose poem is to surrender to a time machine of words for travelling in, and to and from: just as we think we've reached a destination (as much as any of us may identify it as such), or a vanishing point where the poem seems unable to take us further, the cosmos shifts. And wherever we thought we were headed when we embarked, we are now somewhere quite unfamiliar. According to poet Thomas Shapcott, the prose poem 'creates its lyrical frisson by pointing the reader's anticipatory glands in that direction, and then somehow working a change' (Shapcott 2002). Yet this is how all poetry works, irrespective of how it is arranged on the page.

You don't have a stillness, it is what you are. Aura of psalm, apostrophe, held within a grid of lines, you are edged, justified. If you were three-dimensional, the uncontainable (and are you not?) you would be a small teak box, rectangular, inlaid with ivory. Or lacquered, Trappist-tight yet tactile, tissue-thin yet depthless. Yet when I hear you spoken, you are torque of line, seduction, mitre joint. Your marquetry makes ears perceive what eyes do not.

Were I to close my eyes and have someone read me a poem that does not rhyme, I would not be able to tell if it were written in free verse or prose. I know this, because I have tried it. What this experience suggests is that away from the page, in auditory terms at least, there is no perceptible difference between verse and prose poetry. But when we engage with the page, as readers, what we see shapes our interpretive attitude and our response. Poetry apparently masquerading as prose is somewhat unsettling; it offers a sort of visual as well as cognitive dissonance. Am I suggesting a key difference between prose and lineated poems is a visual one, a matter of how they are styled on the page? Yes and no. Because when we engage with the page as writers, the prose poem presents another level of complexity. For a poet like me, more accustomed to writing in free verse, the choice to write in prose means I must resist the almost compulsive pull towards line-breaks; I must accept the invitation to work against and within a framework that can feel counterintuitive. If I do accept, I enter a space of discomfort; but also a space of creative wildness and possibility.

\section{No dancers, only the dance}

I am unsettled. As soon as I encounter a prose poem, there is trepidation, a resistance within me. It is as if I first want to ask, why are you prose? As if you are not already 'complicated' enough, why you then have to go and add another twist, another apparent hurdle, by dressing yourself in prose? Why, isn't the poetic line good enough for you? Like it or not, you are still a poem.

And then I read you. 
You make me stop. You make a sacrament of silence. I think of churches, Book of Common Prayer, language made from liturgy, olden echo, tongue of lolling bell. You're telling me: 'I am pause, negotiation, clog in your way forward. I am the opening no key can fit, the padlock and the door'. You say to me (so tolerant of my ignorance): 'I am deliberate, am denser than a verse. I am the caesura of breath, a ripening sigh, the moment before speech. I am strange yet so familiar: see, no spidery of line, I do not wear my lace outside, yet I am every bit a lyric. I am compressed, decanted, am intense. Not fleet, I am a stillness'.

I think of physicist Fritjof Capra's evocative explanation of quanta, ${ }^{12}$ 'There is motion but there are, ultimately, no moving objects; there is activity but there are no actors; there are no dancers, there is only the dance' (Capra in Adam 2004: 63). Capra's words even read like a prose poem. The simultaneous layering of randomness and control, the synergy of parts and whole combine to mirror prose poetry's tendency to be 'organized as much by sensual as intellectual principle' (Williams 2013: 130). Initially, these principles operate at a different pace to each other, arguably the sensual (the feeling reaction) manifesting before the intellectual (the analytical reaction); before both dissolve into being part of both the dancers and the dance.

Or as poet Robert Bly suggests, 'one's task is not only to snap the picture, but to develop it in a dark room [sic]' (Johnson and Bly 1998). To extend this metaphor, the prose poem is analogue rather than digital. What we experience is akin not only to the instant of the shutter click but also its necessary aftermath: the image slowly surfacing through the swim of chemicals, etch of shape and shade and negative space constructing an eventual completeness. But this is a mediated completeness, predicated on all the things that lie outside of the poem, that remain unsaid. As poet Louise Glück explains:

The unsaid, for me, exerts great power ... It is analogous to the unseen; for example, to the power of ruins, to works of art either damaged or incomplete. Such works inevitably allude to larger contexts; they haunt because they are not whole, though a wholeness is implied: another time, a world in which they were whole, or were to have been whole, is implied. (1994: 73)

Like photographic development, this is a process and a processing that cannot be rushed, involving tacit acceptance on the part of the poem's creator and its reader that, if one is patient, the poem will show itself. Everything required is already there, bounded within time and within 'the law of the margin' (Zawacki 2000: 292) and, implicitly, also outside the words and the margin and time. It just takes a stillness, attentiveness, and surrender to perceive it. Eventually the poem will reciprocate, and yield something of itself. It will join the dance.

I find that writing a poem in prose does not give me the same licence as a lineated poem to play with white space as a proxy for silence. Yet the word-packed state of a prose poem does compel me to try to delineate a sense of silence, and not to shy away from what I am trying to express, even if I must acknowledge, within the poem's limits, the apparent inadequacy of words. But in that apparent inadequacy, that brokenness, I would like to think there is a motion towards Mallarmé's 'significant silence' (Mallarmé in Bruns 2001: 114), and that in 'failing' to offer one thing, maybe I can 
offer a piece of writing that uses its literal incapacity to point towards the thing it cannot express. As Edson counsels, 'Poetry is a thing of gesture and sign, and almost a nonlanguage art. Pure poetry is silence ... words are the enemy of poetry' (1999).

So in the absence of being able to reach beyond language to offer the perfect blank of a silence - a silence that says more than any words ever can - perhaps where the prose poem helps me most is in the process of exploring the feeling of writing; of writing about what it feels like to write. Unable to insert white space, I instead write through it in order to write about it. When I have to fill margin to margin, there cannot be any flinching from this task. The density of words makes me want to be both fastidious and extravagant with them. It reminds me of the compulsion, when conversing with someone, to fill an awkward pause with unguarded chatter. What would it mean were I able to hold my tongue on the page? Would that not be another way of expressing things, not in terms of what they are, but of what they are not?

So now you make me reach beyond the words, explore the almanac of meanings beyond meaning. What is this thing called stillness? Dead man's fingers, summer truffle, stinkhorn, Slippery Jack. I try to write it: silence, calmness, hush, serenity, tranquillity, calm, inaction, noiselessless, the peace, placidity, quietness, quietude.

I write: this is the motionless, the lull. Scion of ancient stille - you hint of standing, standing still. Still. But yet you move. Waxy, lawyer's wig, King Alfred's cakes. You make me stop, but yet you move.

White space, on the page, in pauses between words, where imagination breathes, where life-power tunes its tympani. White makes the sense of sound, where I break off and you appear. You step into white, demand the room to move, and I step back. You forward, I step back. It is like a dance. White space, black marks. The white says silence, black says sound, together we are played, we're emptied, filled, become the copula that's never been. Then I step back and you step forward, then you step back and I step in. Black making sound on white. Staves and fences, sheets and snow.

\section{Conclusion: going naked with imagination}

Prose poetry might be composed of sentences, yet even this 'surface device' (Perloff 1981: 861) is both deceptively simple and infinitely complex. Despite the tidy shape it makes on the page, the prose poem remains resistant to categorisation, not confined as a progressively unfolding statement; flexible enough to accommodate diction and content far more expansive than its crisp edges would suggest. It is tempting to circumvent definitions by trying to define prose poetry in terms of what it is not rather than what it is, but even that would be too limiting a demarcation for something so mercurial. Perhaps Edson put it best when he declared 'there is too much emphasis on 
genre vis-à-vis the prose poem. For me the spirit of the prose poem is writing without genre; to go naked with only one's imagination' (Edson 1999).

Bitter bolete, ear-pick fungus, scaly polypore. Travelling with no agenda, no path till the foot is placed in front of another, the ankle that might twist, the knee that genuflects in mud, the hand that flails at clump of grass ... just like word after word, stumble, hesitation, grasp. Pitch beyond limit. The more I try to find my way, the more the lostness soothes. Like being in mountains without needing to summit, by a river without need of a bridge.

Some days, writing is spade-work, double-digging, clichés springing up like weeds. Days where ideas are untranslatable, Teflon to English, and language and I are not on speaking terms. There is resistance, not only from me fumbling for words, but also the words themselves rejecting me. What if I reject them instead? Deny them? Would that be 'significant silence' (Mallarmé in Bruns 2001: 114)? But writing - a visual 'speech' - inevitably says something, even if only to express the impossibility of articulating that which would appear to be semantically ineffable (Spackman 2012).

Light chasing dark chasing light, along its latitudes the world gets frisked by not-day, not-night, dateline fracturing hemispheres, the opposite, the antipodal, words reverse rehearsal, dark prose of planet ripple, stasis meaning only both and neither, never can be more - or less - than is and isn't. Dawn-prose-twilight-poem: stammer in a sentence iterated, hour by hour. No parole. No parole? A sentence without words? Club foot, plums and custard, rooting shank.

What is the taste of words? If we hold them in our mouths, why can't we taste them, feel them? Crunch of consonant, eel of diphthong, ovum of vowel? How can speech expletive - outcry - just be tremor of air? Living in sound and instant, then is gone, made and unmade in the moment of its utterance. Is thought silent? In our heads, unspoken? Words aloud the page, aloud the dab and dash of a pen, the swish of wrist, the nib is avatar, the ink is silent virus, moldwarp burrowing along, just beneath the surface, there I am, trying to slide between the nib and that which would be scratched out from my fingers, hand and arm. Trying to feel the groove of thought, its carve through language skin. Its sting inflicts the cure.

What better way to push at the boundaries of language? The prose poem, already subversive, already a trickster, is mountain, need, and summit. Soft as river, hard as bridge. Will it take me nearer to Mallarmé's 'significant silence'? I have to keep writing it to find out.

Witches' butter, golden spindles, bell-shaped mottlegill. 


\section{Endnotes}

1. Fungus names are sourced from Phillips (1994 [1981]).

2. The action or process of trying or testing (OED 2017).

3. Apophasis is a Greek word with a complex meaning. At its most basic level, it can be understood as the practice of defining things in terms of what they are not. Etymologically, and as originally used by Plato and Aristotle, the word apophasis 'simply meant "negation"' (Franke 2007: 1), or denial. According to poet and scholar Reginald Gibbons, apophasis combines 'a verb for "to say" (phanai) and a prefix (apo) which in this use means "away from, down from, far, from", (Gibbons 2007). The Oxford English Dictionary gives the meaning 'to "speak off”, deny' (OED 2015). Apophasis is 'un-saying or speaking-away' (Sells 1994: 2). But by the time of the early Christian mystics (around four or five hundred years after Christ) apophasis had moved beyond the basics of negative phraseology to encompass all that is 'beyond words - and indeed beyond the limits of language altogether' (Franke 2007: 2).

4. For a history and discussion of the development of apophasis in religious and secular texts, see Sells (1994), Wolters (1978), Franke (2007), Davies and Turner (2002), MacCulloch (2014), Mortley (1986).

5. See Spackman (2012), and Marco (2016).

6. The full quotation from Alazraki is: 'the poet is condemned to words but must transcend them' (Alazraki 1976: 41)

7. See, for example, Hetherington and Atherton (2015), Brophy (2003), Lehman (2003), Sànchez (2009).

8. Prosimetrum: 'First coined to designate those mixed-mode Eur. med. works, of which Boethius's Consolation of philosophy and Dante's Vita nuova are the masterpieces, the term has since been expanded to include texts that, from other times and cultures, also feature prose with verse inserts' Princeton Encyclopedia of poetry and poetics 1509-10.

9. 'a dramatic dialogue in the language of courtly love ... between Lady Love (Dame Amour), the Enfranchised Soul (L'Ame enfranchie), and Reason' (Franke 2007: 278).

10. For discussion on the techniques of the early Christian mystics see Franke (2007).

11. Known as Dionysius (or Denys) the Areopagite, or Pseudo-Dionysius, this person is believed to be a sixth-century monk from Syria (Franke 2007).

12. 'The word 'quantum' ... means a unit of action which contains energy and time' (Adam 2004: $63)$.

\section{Works cited}

Adam, B 2004 Time Cambridge: Polity Press

Agamben, G 1991 'Language and death: The place of negativity' Theory and history of literature (trans KE Pinkus and M Hardt), V78, Minneapolis: University of Minnesota

Alazraki, J 1976 'Music as silence in Neruda's eight posthumous books of poetry' Books abroad 50, 1: $40-5$

Beckett, S 1976 [1959] Molloy, Malone dies, the unnamable London: John Calder Publishing

Brophy, K 2003 Explorations in creative writing Melbourne: Melbourne University Press

Bruns, GL 2001 [1974], Modern poetry and the idea of language: A critical and historical study Illinois: Dalkey Archive Press

Caputo, JD 1997 The prayers and tears of Jacques Derrida: Religion without religion Indianapolis: Indiana University Press 
Cushman, S, C Cavanagh and P Rouser (eds) 2012 Princeton encyclopedia of poetry and poetics Princeton: Princeton University Press

Davies, O and J Turner (eds) 2002 Silence and the word: Negative theology and incarnation Cambridge: Cambridge University Press

Derrida, J 1996 'How to avoid speaking: denials' (trans K Friedan) in S Budick and W Iser (eds) Languages of the unsayable: The play of negativity in literature and literary theory, Stanford: Stanford University Press, 3-70

Derrida, J 1995 On the name Stanford: Stanford University Press

Derrida, J 1982 'Différance’ Margins of philosophy (trans A Bass), Chicago: University of Chicago Press, 3-27

Dickinson, E 1975 Complete poems (ed TH Johnson), London: Faber and Faber

Dickinson, E 1971 Emily Dickinson: Selected letters (ed TH Johnson), Cambridge MA: Belknap

Dickinson, E 1959 Selected poems and letters of Emily Dickinson (ed RN Linscott), New York: Anchor Books

Dionysius, 1978 The cloud of unknowing and other works (ed C Wolters), London: Penguin Classics

Dronke, P 1994 Verse with prose from Petronius to Dante: The art and scope of the mixed form Cambridge MA: Harvard University Press

Drury, J 1991 Creating poetry, Cincinnati: Writer's Digest Books

Edson, R 1999 'Interview: The art of the prose poem' The prose poem: An international journal 8, 53 at http://www.webdelsol.com/tpp/ (accessed 20 October 2017)

Eliot, TS 1974 Collected poems 1909-1962 London: Faber and Faber

Franke, W 2014 A philosophy of the unsayable Notre Dame: University of Notre Dame Press

Franke, W (ed) 2007 On what cannot be said: Apophatic discourses in philosophy, religion, literature, and the arts, V1, Notre Dame: University of Notre Dame Press

Gibbons, R 2007 'On apophatic poetics: Part one' American poetry review 36, 6: 19-23, http://aprweb.org/ (accessed 22 April 2017)

Glück, L 1994 Proofs \& theories: essays on poetry Hopewell: Ecco Press

Heidegger, M 2000 Elucidations of Hölderlin's poetry (trans K Hoeller), Amherst: Humanity Books

Heidegger, M 1971 On the way to language (trans PD Hertz), San Francisco: Harper \& Row

Hetherington, P and C Atherton 2015 'Unconscionable mystification'?: Rooms, spaces and the prose poem' New writing 12, 3: 265-81

Johnson, J 2006 'Introduction’ The Mississippi review 34, 3: 7-9

Johnson, P and R Bly 1998 'Interview: The art of the prose poem' The prose poem: An International journal 7, 52 at http://www.webdelsol.com/tpp/ (accessed 20 October 2017)

Kuusisto, SD Tall and D. Weiss (eds) 1995 The poet's notebook: Excerpts from the notebooks of 26 American poets New York: Norton

Lehmann, D 2003 'The prose poem: An alternative to verse' The American poetry review (March/April): 45-9

Longenbach, J 2008 The art of the poetic line Saint Paul: Graywolf Press

MacCulloch, D 2014 Silence: A Christian history New York: Penguin Books

Marco, SR 2016 'Expressiveness, ineffability, and comparisons' in F Dorsch and D-E Ratiu (eds),

Proceedings of the European Society of Aesthetics 8: 393-403

Marcus, M 1999 'The Fu: China and the origins of the prose poem' The prose poem: An international journal 8, 64 at http://www.webdelsol.com/tpp/ (accessed 20 October 2017) 
Mortley, R 1986 From word to silence: 1. The rise and fall of logos Bonn: Hanstein

Mortley, R 1986 From word to silence: 2. The way of negation, Christian and Greek Bonn: Hanstein

Novey, I 2013 'The prose poem as mysterious man with an accent' Harriet: A poetry blog at https://www.poetryfoundation.org/harriet/2013/04/the-prose-poem-as-mysterious-man-with-an-accent/ (accessed 16 April 2017)

O’Hara, F (n.d.) 'Why I am not a painter' at https://macaulay.cuny.edu/eportfolios/smonte10/files/2010/08/OHara-Poems.pdf (accessed 10 June 2017)

O’Hara, F 2017 Oxford English dictionary Oxford: Oxford University Press

Paterson, D 1999 The eyes: A version of Antonio Machado London: Faber and Faber

Perloff, M 1981 'The linear fallacy' The Georgia review 35, 4: 855-869

Phillips, R 1994 [1981] Mushrooms and other fungi of Great Britain and Europe London: Macmillan Reference

Porete, M 2007 'Marguerite Porete' in W Franke (ed) On what cannot be said: Apophatic discourses in philosophy, religion, literature, and the arts V1, Notre Dame: University of Notre Dame Press, 277-84

Rumi, 1999 [1898] Selected poems from the Divani Shamsi Tabriz (trans R A Nicholson) Abingdon, Oxon: Routledge

Rumi, 1994 The teachings of Rumi (The Masnavi): The spiritual couplets of Jalaludin Rumi (trans I Shah), London: Octagon Press

Sells, M 1994 Mystical languages of unsaying Chicago: University of Chicago Press

Shapcott, T 2002 'The prose poem’ TEXT 6, 2 at http://www.textjournal.com.au/oct02/letters.htm (accessed 16 April 2017)

Sànchez, JM 2009 'The prose poem: An apology’ The Southern Review (Winter): 175-84

Spackman, J 2012 'Expressiveness, ineffability, and nonconceptuality' The journal of aesthetics and art criticism 70, 3: 303-14

Steiner, G 1967 Language and silence: Essays 1958-1966 London: Faber and Faber

Wainwright, PO, G Hinkle, ML Sogin and SK Stickel 1993 'Monophyletic origins of the metazoa: An evolutionary link with fungi' Science 260.5106: 340

Williams, R 2013 The poetry toolkit: The essential guide to studying poetry $2^{\text {nd }} \mathrm{ed}$, London:

Bloomsbury Academic

Wittgenstein, L 1961 Tractatus logico-philosophicus (trans DF Pears and BF McGuinness), London: Routledge and Kegan Paul

Wolters, C (ed) 1978 The cloud of unknowing and other works London: Penguin Classics

Wright, C 2003 A short history of the shadow New York: Farrar, Straus and Giroux

Wright, C 2002 Halflife: Improvisations and interviews 1977-87 Poets on Poetry Series, Ann Arbor: University of Michigan Press

Wright, C 2000 Negative blue: Selected later poems New York: Farrar, Straus and Giroux

Zawacki, A 2000 'Accommodating commodity: The prose poem' The Antioch Review 58, 3: 286-303 